\title{
Population ecology of the multivoltine Neotropical gall midge Eugeniamyia dispar (Diptera, Cecidomyiidae)
}

\author{
Milton de S. Mendonça, Jr. ${ }^{1,2} \&$ Helena P. Romanowski ${ }^{1}$
}

\begin{abstract}
1. Programa de Pós-Graduação em Biologia Animal, Departamento de Zoologia, Instituto de Biociências, Universidade Federal do Rio Grande do Sul, Av. Bento Gonçalves 9500, Bloco IV, Prédio 43435, 91501-970, Porto Alegre, RS, Brazil (milton.mendonca@ufrgs.br).

2. Departamento de Ecologia, Instituto de Biociências, Universidade Federal do Rio Grande do Sul, Av. Bento Gonçalves 9500, Bloco IV, Prédio 43422, 91501-970, Porto Alegre, RS, Brazil.
\end{abstract}

\begin{abstract}
Our understanding of the population ecology of insect gallers is largely built on examples from temperate zones, but tropical and subtropical gallers may present distinct patterns of abundance and distribution across time. Eugeniamyia dispar Maia, Mendonça \& Romanowski, 1996 is a multivoltine Neotropical cecidomyiid that induces spongy leaf galls on Eugenia uniflora (Myrtaceae). Galls were censused in the urban area of Porto Alegre, southern Brazil on six plants at two sites, for two years, at roughly weekly intervals. Overall 9,694 eggs, galling attempts and galls were counted. New galls continuously appear on developing leaves, but galls with live inducers are absent from June to at least early August. Galls on a same shoot develop synchronically, thus the shoot is probably the unit for oviposition. Given the also synchronic appearance of galls on different plants on a site, it seems midges can disperse and attack close-by plants. Gall cohorts varied in abundance by two orders of magnitude; there were more galls during summer than for spring and autumn, in a wave-like pattern. Host plant leaf production was seasonal, with low production during winter and cyclic production during the rest of the year. Perhaps because of this very variable pattern, gall abundance did not follow leaf production: this galler is not synchronised with its host at least during most of the year. This multivoltine gall inducer with "labile" galls, short development time, partially overlapping generations and low host synchronisation differs from the commonly studied species of the temperate regions providing a subject for ecological comparisons.
\end{abstract}

KEYWORDS. Brazil, Eugenia uniflora, gall-inducer, Myrtaceae, population dynamics.

RESUMO. O conhecimento sobre a ecologia de populações de insetos galhadores é construída principalmente sobre exemplos de zonas temperadas, mas galhadores tropicais e subtropicais podem apresentar padrões distintos de abundância e distribuição ao longo do tempo. Eugeniamyia dispar Maia, Mendonça \& Romanowski, 1996 é um Cecidomyiidae Neotropical multivoltino que induz galhas esponjosas sobre Eugenia uniflora (Myrtaceae). Galhas dessa espécie foram recenseadas na área urbana de Porto Alegre, sul do Brasil, em seis plantas de dois sítios, durante dois anos, em intervalos semanais a quinzenais. Ao todo, 9.694 ovos, tentativas abortadas de galhas e galhas foram contabilizados. Novas galhas continuamente aparecem em folhas em desenvolvimento, mas galhas com galhadores vivos no interior estão ausentes entre junho e o início de agosto. Galhas de um mesmo ramo desenvolvem-se sincronicamente, o ramo sendo provavelmente a unidade espacial de oviposição. Dada a sincronia no aparecimento de galhas entre plantas de um mesmo sítio, parece que os insetos podem dispersar e atacar plantas próximas. Coortes de galhas variaram em abundância em até duas ordens de magnitude; houve mais galhas durante o verão do que durante primavera e outono, num padrão anual de onda. A produção de folhas novas pela hospedeira foi sazonal, com produção baixa durante o inverno e cíclica durante o resto do ano. Talvez por esse padrão variável, a abundância de galhas não seguiu a produção de folhas: este galhador não sincroniza com a hospedeira, ao menos durante a maior parte do ano. Este galhador multivoltino com galhas "lábeis", curto tempo de desenvolvimento, gerações parcialmente sobrepostas e baixa sincronia com a hospedeira difere de espécies comumente estudadas das regiões temperadas, sendo uma fonte potencial para comparações ecológicas.

PALAVRAS-CHAVE. Brasil, Eugenia uniflora, galhador, Myrtaceae, dinâmica de populações.

Insect gall inducers are good subjects for ecological work on populations because galls being sedentary enables a relatively easy following of cohorts and generations (RAMAN et al., 2005). Sometimes even the evidence of emergence or death of the insects remain identifiable in the galls for rather long times (REDFERN \& CAMERon, 1978). Therefore, densities can be more easily assessed and possible causes of mortality determined (Hails \& CraWley, 1992), including host plant responses such as hypersensitivity reaction, that leave no proper galls but scars (Santos \& Fernandes, 2010). Thus, gallers and gall-midges in special have been intensively studied at the population level (YuKawa \& ROHFRITSCH, 2005).

However, not all galls are as exemplary as the most commonly studied temperate species: some are multivoltine, with many generations requiring long sampling regimes across a year, and some galls can be more "short-lived", being shed from the plant (WiLliams \& Whiтнам, 1986) or decaying rapidly because built from softer plant tissues. Moreover, especially in the gall-inducing Cecidomyiidae, a range of life history strategies and population dynamics exists (YUKAWA, 1987; YuKAWA \& Rohfritsch, 2005), as yet largely unexplored.

Eugeniamyia dispar Maia, Mendonça \& Romanowski, 1996 is a galler on the shrub Eugenia uniflora L. (Myrtaceae), known as Surinam cherry. Eggs are oviposited on developing leaves and shoots of the host. The first instar larva induces the gall, develops within it and leaves it to pupate in the soil (MENDONÇA \& Romanowski, 2002b). The gall is a spongy whitish unilocular sphere with $3.5-4 \mathrm{~mm}$ in diameter, formed mainly by hypertrophy of the parenchymatous tissue (Mendonça et al., 1998). Due to its structure, galls dry up and decompose or desiccate in a few weeks. Shoot galls are rare (less than $1 \%$ of the galls), but have a similar structure to leaf galls, and sometimes can lead to shoot tip mortality when they desiccate (pers. obs.). Population fluctuation of this species across two years of sampling at two nearby sites is presented along with data on host plant resource dynamics. The aim of this 
research was thus to reveal the temporal structure of the sampled Eugeniamyia dispar galler populations, its relation to host plant phenology, and also to quantify galler abundance at the host plant level.

\section{MATERIAL AND METHODS}

Study area, sites and plants. Observations were carried out in the urban area of Porto Alegre $\left(30^{\circ} 1^{\prime} \mathrm{S}\right.$, $51^{\circ} 13^{\prime} \mathrm{W}$ ), state of Rio Grande do Sul, Brazil. It has a humid subtropical climate (ST UM according to the classification by CAMARGO (1991)), with abundant rainfall - about 1,300 $\mathrm{mm}$ per year - and no dry season. Average annual temperature is at $19.5^{\circ} \mathrm{C}$ (MALUF, 2000), but monthly temperatures vary from $9^{\circ} \mathrm{C}$ (June, July) to $22^{\circ} \mathrm{C}$ (January, February), thus with a not too strong seasonal component.

Two sampling sites (A and B) were near large plots of woods (ca. 10 ha) in late secondary succession (more detailed information can be found in MENDONÇA \& ROMANOWSKI 2002b). Sites were chosen for the presence of galls during the previous year and easy access. Each site had three E. uniflora plants: a larger plant $1.8 \mathrm{~m}$ tall, and two shorter ones about $1 \mathrm{~m}$ tall. The larger plants are numbered one (i.e. A1 and B1), and the smaller plants 2 and 3. Sites are thus expected to be similar in the amount of plant resource provided to gallers occurring there. Apart from the naturally occurring host plants, two $E$. uniflora saplings were experimentally introduced to site A in the spring of 1994 to verify whether colonisation to nearby plants was possible for resident gallers. These were collected from Saint-Hilaire Park, a natural area in Porto Alegre, and kept in flowerpots. They were $30 \mathrm{~cm}$ tall and were placed $3 \mathrm{~m}$ north of the A1 plant.

Site A plants were in a house garden and site B plants were on the public walkway. Because they were in a public area, plants at site B were inadvertently pruned during the second year of sampling (November 1994).

Sampling. Samples were obtained every 3-4 days for site A in the first year of sampling (October 1993 to June 1994), with only plant A1 sampled. For site B during the same period, and for both sites from August 1994 to September 1995, sampling was done weekly except for June and July when it was fortnightly. For B1 during the first half of the 1993/1994 period only the number of galled leaves was recorded, galls being counted from the end of February on. Number of galls before that was estimated by multiplying the recorded number of galled leaves by the average number of galls per leaf for that plant in all later samples.

All galls present on a site were recorded on each sampling occasion. Eggs were counted on the leaves when possible, but they are small and thus difficult to find. First instar mortality before gall induction was identifiable as aborted gall-inducing attempts curbed by hypersensitive reaction (Fernandes, 1998). These are small (about $1 \mathrm{~mm}$ or less) brown or reddish spots of leaf tissue found almost exclusively on galled leaves. We employed plant histology techniques to characterise their structure (Mendonça et al., 1998). They are composed of dead leaf tissue, surrounded by a ring of dead but engorged cells enclosing the area where at the centre a gall-inducing attempt was made. To be certain the origin of the reaction was a galling attempt, only such spots on galled leaves and shoots were counted. Thus, numbers of galls represent a sum of actually induced galls plus aborted attempts, corrected by egg mortality. We thus refer to estimated population numbers of gallers instead of galls. The exit hole of the third instar larva could be identified (differing from parasitoid holes, MEndonçA \& RomANOwski, 2002a), and open galls were thus also counted.

Host plant leaf phenology was recorded for site A from August 1994 to September 1995 and for site B for the whole sampling period (October 1993 to September 1995). The total number of shoot tips producing or having recently produced leaves was counted for all plants. New leaves are easily identified in E. uniflora since it shows delayed-greening (NUMATA et al., 2004): brand new leaves are bright red and change toward brownish and finally green hues in a few weeks. Dark brown, red and bright red leaves were counted in this case to evaluate galling midge oviposition site abundance. The coincidence of leaf production and the number of galls present was tested with Pearson correlations between these variables for each site (across two years for site $\mathrm{B}$ and one year for site $\mathrm{A}$ ). We also tested lagging the number of galls relative to leaf production and then correlating to check for delays in galler response to leaf production - in that case a Bonferroni correction was used to compensate for multiple testing. Lags were 1, 2 and 3 time steps (samples), which corresponds to approximately 4, 7 and 11 days on average for site $\mathrm{A}$ in 1993/1994 and 7, 14 and 21 days on average in all other cases. These tests were implemented in PASt software (HAMmer et al., 2001).

\section{RESULTS}

Overall 9,894 eggs, galls and hypersensitive aborted galling attempts were counted, 4,491 during the first year (Spring 1993 - Autumn 1994) and 5,403 during the second year (Spring 1994 - Autumn 1995). Eugeniamyia dispar is multivoltine: new galls are constantly appearing, developing and senescing (Figs 1-3) apart from the early- and mid-winter period (June/ July, Figs 4, 5). Midge eggs can be observed only on very young (bright red or red) leaves and shoots, and young galls are also found on leaves at this stage; thus, egg development seems to be fast. These midges have also fast larval development: galls increase in size in about a week to a mature form, and exit holes appear in another week or less. Generation overlap is dependent on the time of the year, being less marked in late winter 

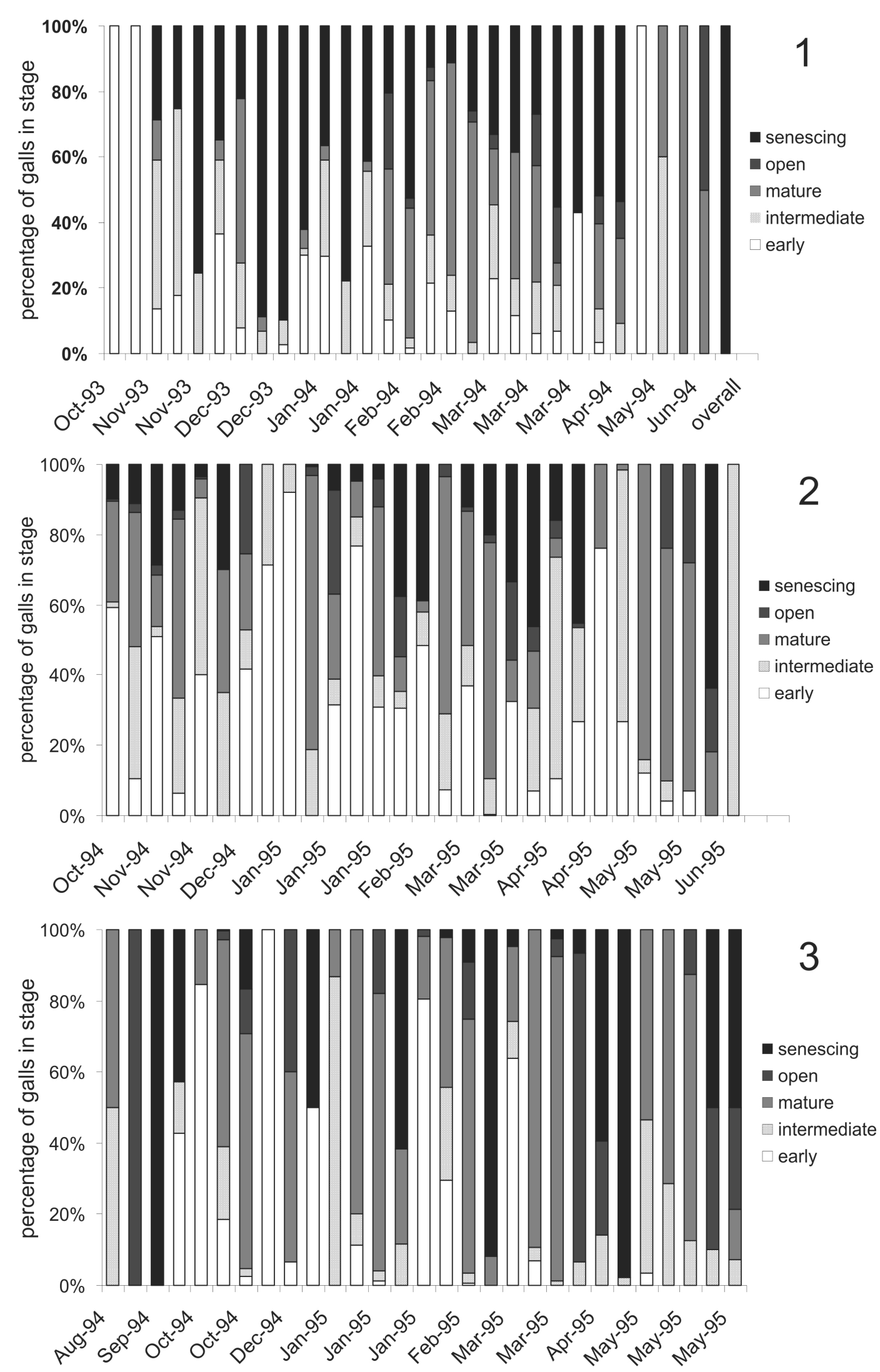

Figs 1-3. Proportion of Eugeniamyia dispar Maia, Mendonça \& Romanowski, 1996 galls at different life stages from 1993 to 1995 on Eugenia uniflora host plants at two sites in Porto Alegre, RS, Brazil: 1, site A, 1993-1994; 2, site A, 1994-1995; 3, site B, $1994-1995$ (data for 1993-1994 was not gathered, see text for detail). Light tones represent early stages and darker tones older ones (including empty drying/senescing galls). 
or late fall (site A: October to November 1993, May to June 1994; site B: August-September 1994, May 1995, Fig. 1).

Galls appear and develop almost always synchronically at the level of the galled shoot. In a few cases there were galls in very different stages of development (early galls along with mature ones) on the same shoot, and only once this occurred on the same leaf. Galls appearing synchronously on a shoot are henceforth called cohorts. Cohorts can appear on only one plant or simultaneously on two or more plants of the same site: this has happened for both sites and for both sampling years. A third of the cohorts identified in the 1994/1995 season for site A appeared on more than one plant, one in January 1995 occurring on the three of them. The plant pots introduced experimentally at site A harboured two different gall cohorts each, both simultaneously with other plants at the site.

The appearing of the first galls seemed to change among years and sites (site A: 13/11/1993, 07/10/1994, 14/09/1995, 03/09/1996; site B: 27/10/1993, 31/08/1994, $11 / 08 / 1995)$. There seems to be a trend for the first
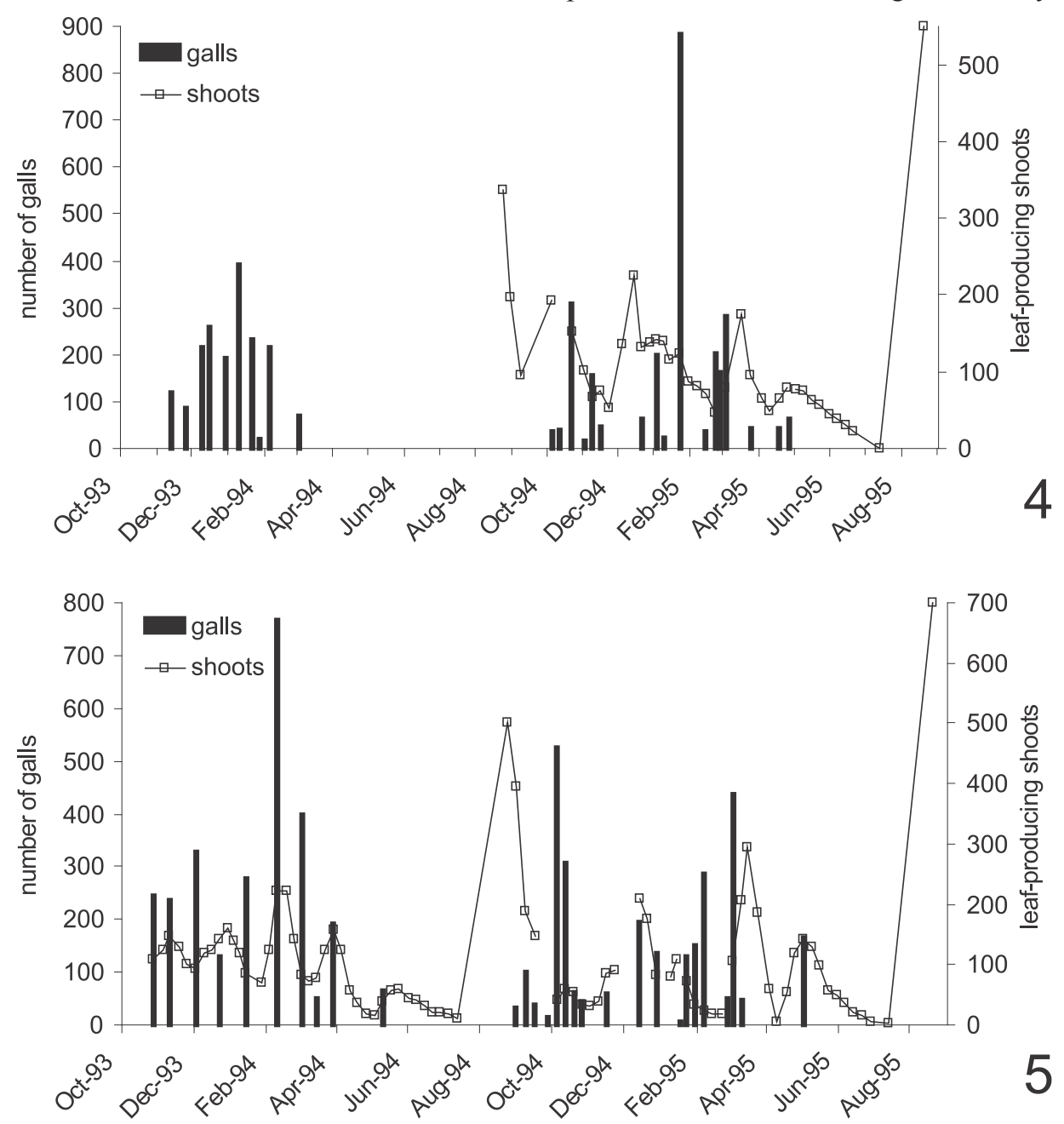

Figs 4, 5. Abundance of Eugeniamyia dispar Maia, Mendonça \& Romanowski, 1996 from 1993 to 1995 on Eugenia uniflora host plants at two sites in Porto Alegre, RS, Brazil. Bars represent successive cohorts of gallers sampled on the plants, open squares connected with lines are number of leaf producing shoots (leaves with delayed greening, see text) on each site: 4, site A; 5, site B. The grey arrow in Fig. 5 represents the inadvertent pruning of the plants. Note differences in scale between graphs and axes. ovipositions to occur earlier on subsequent years for each site. The occurrence of galls varied considerably among plants. Larger plants had galls during longer and more continuous periods, smaller plants had galls intermittently, either in the beginning (plants A2 and A3) or at the end of the period galls are present (B3).

Plants on both sites A and B had 10 distinguishable cohorts of developing gall inducers during the 1993/1994 season (Fig. 2). However, site B cohorts are more spaced out. The last cohorts contribute strongly to this time span, occurring a month or more apart. In the 1994/1995 season nearly twice as many cohorts were recorded: 17 on site A, and 19 on site B (Fig. 2). An important aspect distinguishes the sites: in November 1994 plants in site $\mathrm{B}$ were pruned, altering plant size, phenology and gallinducer dynamics as well (grey arrow on Fig. 2). On this year the sites harbour galls for different periods of time, with site A plants hosting galls during a shorter time than site B plants. Again, the last two cohorts for site B appeared a long time (nearly two months) apart.

The number of gallers on each plant in each cohort spanned three orders of magnitude, varying from 5 to 
885 (Fig. 2). Population size on site A was nearly twothirds that on site $\mathrm{B}$ during the first season, but not on the second, probably because of the pruning event reducing population levels in site B. For both sites in both years the number of gall inducers peaks for summer cohorts (January or February). There seems to be a wave-like pattern in abundance (e.g. 1993/1994 for site A, Fig. 2). The pruning event in site B seemingly interferes with the summer peak; if only the period after the pruning is considered, however, a wave pattern can also be seen.

The host plant leaf production appears to have at least three distinct periods (Figs 4, 5): first, in late winter/ early spring (August/September), there is a general sprouting of new leaves when more than twice as many shoots are producing leaves than at any other time in the year. Second, across spring, summer and early autumn leaf production occurs in pulses, peaking and then tapering rather more slowly; the number of pulses per year seems to vary from four to five, depending on the year and site. Finally, leaf production appears to stop or at least reach the lowest levels during the end of autumn and early winter.

Galler abundance does not coincide with resource abundance ( site A: $\mathrm{r}^{2}=0.014, \mathrm{p}=0.625 ;$ site $\mathrm{B}: \mathrm{r}^{2}=0.012$, $\mathrm{p}=0.556$ ). Gallers do not lag behind leaf production either, as correlations did not increase to significance when adopting lags in gall abundance relative to leaf production (site A: lag-1: $\mathrm{r}^{2}=0.037$, lag-2: $\mathrm{r}^{2}=0.069$, lag-3: $r^{2}=0.016$; site $B:$ lag- $1: r^{2}=0.002$, lag-2: $r^{2}=$ 0.021 , lag-3: $\left.r^{2}=0.004\right)$. Because galls are certainly absent during part of the winter and leaf production was measured for this period as well, we included zero gall abundance data for every month without galls for each site in the correlations. This did not affect results appreciably.

\section{DISCUSSION}

GAGNÉ (1994) states that many gall midge species in the tropical Neotropics produce generations continuously, whilst others in temperate to cold or dry areas do not. Eugeniamyia dispar conforms to the pattern but at an intermediate situation: in the seasonal subtropical region of southern Brazil this insect is absent in larval form inside galls only for a short winter period. Although host alternation for multivoltine Cecidomyiids is known (YuKawa \& Rohfritsch, 2005), we believe an alternative winter host does not seem likely: the period $E$. dispar is absent from E. uniflora can be short and occurs during the cold season when development is slower; also, most plants in southern Brazil have restricted growth during winter, like E. uniflora; finally, in a urban environment the range of possible alternative hosts is meagre, and finding them would be a significant problem for the insects. Thus, it seems an extended larval or pupal period in the soil could be the most parsimonious answer for the wintering period. The slowing down of gall development observed for early spring and late autumn also indicates such a possibility. There are examples of temperate galling Cecidomyiids with soil pupation showing a dormancy stage in soil during winter, as the lentil gall midge Contarinia lentis (Kolesik, 1993). A tropical example would be Schyzomyia sp.: larvae drop from the flower galls on Pimenta dioica in Jamaica and remain dormant until the following spring (PARNELl \& ChAPMAN, 1966).

In a work on the parasitoid assemblage of gall midges Hawkins \& GAGNÉ (1989) analysed biological and population characters (pupation site, voltinism) of 191 species of Cecidomyiidae. Approximately 31\% of the studied Cecidomyiidae were multivoltine, that is, had three or more generations a year. Most multigenerational work done on the population dynamics of gall inducers is from temperate areas, and show univoltine or bivoltine populations. There are even classifications based on different life histories of univoltine gall-midges (Yukawa, 1987; Yukawa \& Rohfritsch, 2005), but there is none for multivoltine ones. This example from a subtropical species living in a moderately seasonal environment showing multivoltinism with overlapping generations suggests there could be a range of species with different population biologies not yet taken into consideration.

Many Cecidomyiidae have galls found throughout the year in the tropics (GAGNÉ, 1994, other examples in Maia, 1999; Maia \& Tavares, 2000), and even in the subtropics, BRIGGS \& LATTO (2000) registered continuous gall production by Rhopalomyia californica Felt, 1908. However, the number of generations for tropical and subtropical multivoltine gall-midges is not commonly recorded with any degree of precision, except for species that are pests. An exception would be Asphondylia boerhaviae (Freeman \& Geoghagen, 1989), which is known to have about 17 generations per year in Jamaica (certainly more than E. dispar). A suggestion is that many galling midge species recorded as multivoltine can also be "overlappers", that is, sampling regimes are not usually designed to reveal short term trends and events and this prevents defining generations as discrete or continuous.

In this midge species the degree of overlapping seems to increase with gall-inducer abundance. Discrete galling events for entire isolated plants were found in the tropical gall midge A. boerhaviae (FREEMAN \& Geoghagen, 1989), similarly to the discrete appearance (and development) of galls in shoots and among shoots of same and different plants found for E. dispar. This can come from oviposition of a single or few females during short periods of time (Freeman \& Geoghagen, 1989). The ovipositions observed to constitute cohorts could actually be due to a small number of ovipositing adults, but this effect could disappear for larger populations, for example the beginning of the 1994/1995 season for site $\mathrm{B}$, when many cohorts followed one another. With more 
inducers present, an increase in the variance in developing time could generate heterogeneity in the time span between cohorts, and thus more cohorts as well. Thus, larger populations would overlap more. An analogous phenomenon was described for Dasineura affinis (Kieffer, 1886) (BIRCH et al., 1992) in which the overwintering generation emerges "en masse" whilst in the following generations the flight period of the adults is spread over time. Polymodal emergence is also found in the Machilus sp. leaf gall midge, among others (MAEDA et al., 1982).

The influence of host plant density and/or spatial configuration on galler abundance has been explored for different systems (Cuevas-Reyes et al., 2004; McGeoch $\&$ PrICE, 2004), and in some cases galler metapopulation structures arise, but usually associated with that of the plant (EBer \& BRANDL, 1996). E. dispar populations seem to use nearby host plants in artificial (urban) patches such as those sampled here as a single spatial unit. Cohorts occur simultaneously on more than one plant on a site, suggesting either many females emerge simultaneously or females can move from shoot to shoot. This is further indicated since galls appeared on the experimentally introduced plants, also simultaneously with the main plant on the site. It remains to be seen whether in natural settings the spatial dynamics of host plants mirrors the one found here.

According to MANI (1964), E. dispar would belong to the majority of gall inducers, which develop strictly at a definite time of the vegetative season of the host plant. However, in the case of E. uniflora the vegetative season extends almost throughout the year, albeit with strong variation in the amount of galler resource produced. It cannot be ruled out that other factors, as temperature, limit the presence of $E$. dispar galls during what is the harshest part of winter in southern Brazil (June and July, with average minimum temperatures at $9.8^{\circ} \mathrm{C}$, WorldClim - Hismans et al., 2005). Nevertheless, this is probably unlikely for a simple reason: the "spring" budburst for E. uniflora actually occurs by the end of August, when temperatures can still be very low (average minimum temperatures at $11^{\circ} \mathrm{C}$ for this month, WorldClim), and the first galls were found shortly after at least once ( $31^{\text {st }}$ of August 1994 for site B).

Synchronization of galler life history to oviposition resource (inductive host plant tissues) has been deemed an essential adaptation for galling insects (YUKAWA, 2000), and figures as an important factor in galler speciation by host shift (MendonçA, 2001). However, leaf production by E. uniflora appears to be too variable for $E$. dispar to track. In strongly seasonal settings, as temperate and arid regions, plants have leaf bursts timed to occur with the best possible environmental conditions. In such cases, galler synchronisation can indeed be feasible allowing the insects to better exploit their hosts. In a mildly seasonal region such as the Brazilian subtropics, leaf production can occur almost year round, as in the tropics, but with a spring burst still present, and a short winter cessation or slowing down. Thus, different seasons have different leaf production patterns for gallers, and synchronisation would be a very complex task. It seems $E$. dispar is able to track the spring budburst, as temperate and dry region species do, with the first post-winter generation appearing after leaf production is increased, while abiotic conditions are still harsh (cold). However, further leaf production peaks across the year are not followed by cohorts in a synchronised fashion. As we do not understand the synchronisation of tropical galling species to their hosts sufficiently (YUKAWA, 2000), it may be that this springsummer-autumn synchronisation breakdown of $E$. dispar reflects a tropical pattern. Thus, the Brazilian subtropics would warrant their name as an intermediate situation between the temperate and tropic regions, with species espousing a mix of ecological patterns characteristic of both.

The summer population peak could result from higher temperatures through some correlated population variable as higher larval survival or lower mortality from predators or parasitoids. Because of plant pruning in site B the population peak came later than usual, and appeared to depend on a build up of the population in previous cohorts/generations. Since pruning delayed leaf production levels as well, this indicates in turn that oviposition resource may be responsible for the summer gall peak: with more leaf producing shoots available, galler populations can reach higher levels - even though we found no correlation between leaf production and gall abundance overall. It is known that seasonal variation can lead to changes in galler population directly through climatic events (rainy season) and indirectly (rainy season leading to more plant organ production/more oviposition sites), although the exact mechanism for the direct effect is currently unknown (ARaúJo \& Santos, 2009). In the case of $E$. dispar, only future experimental tests could help disentangle the influence of abiotic factors and leaf production on the yearly galler abundance.

Multivoltine gall inducers provide a good subject for population studies because more data points can be gathered in a shorter time generating longer time series. Nevertheless, more constant sampling is also required. Eugeniamyia dispar is perhaps an extreme example, with more than 10 cohorts occurring on a given plant on a given year. Studies of abundance in time for univoltine systems usually take many years before time series are long enough and meaningful dynamics emerge (e.g. Redfern \& CAmeron, 1978; Soné, 1987; Wool, 1990), and sometimes definitive answers may require even longer time spans (e.g. REDFERN \& CAMERON, 1993, REDFERN \& HUNTER, 2005).

This work provides evidence for more complex dynamics of voltinism and abundance than usually assumed for gall inducers. These insects remain a prolific source of information for population ecology, providing valuable insights with straightforward sampling procedures. 
Acknowledgements. We wish to thank FAPERGS and CAPES for scholarships to MMJ. This paper is contribution number 446 to the Departamento de Zoologia, Instituto de Biociências, UFRGS.

\section{REFERENCES}

Araújo, W. S. D. \& Santos, B. B. D. 2009. Efeitos da sazonalidade e do tamanho da planta hospedeira na abundância de galhas de Cecidomyiidae (Diptera) em Piper arboreum (Piperaceae). Revista Brasileira de Entomologia 53(2):300-303.

Birch, M. L.; Brewer, J. W. \& Rohfritsch, O. 1992. Biology of Dasineura affinis (Cecidomyiidae) and influence of its gall on Viola odorata. In: Shorthouse, J. D. \& Rohfritsch, O. eds. Biology of Insect-Induced Galls. Oxford, Oxford University Press. p. 215-226.

BRiggS, C. J. \& LATto, J. 2000. The effect of dispersal on the population dynamics of a gall-forming midge and its parasitoids. Journal of Animal Ecology 69:96-105.

CAmargo, A. P. de. 1991. Classificação climática para zoneamento de aptidão climática. In: Congresso Brasileiro de Agrometeorologia, 7., 1991, Viçosa, MG. Resumos... Viçosa, Sociedade Brasileira de Agrometeorologia, Universidade Federal de Viçosa. p. 126-131

Cuevas-Reyes, P.; Quesada, M.; Hanson, P.; Dirzo, R. \& Oyama, K. 2004. Diversity of gall-inducing insects in a Mexican tropical dry Forest: the importance of plant species richness, life forms, host plant age and plant density. Journal of Ecology 92:707-716.

Eber, S. \& BrandL, R. 1996. Metapopulation Dynamics of the Tephritid Fly Urophora cardui: An Evaluation of IncidenceFunction Model Assumptions with Field Data. Journal of Animal Ecology 65:621-627.

Fernandes, G. W. 1998. Hypersensitivity as a phenotypic basis of plant induced resistance against a galling insect (Diptera: Cecidomyiidae). Environmental Entomology 27:260-267.

Freeman, B. E. \& Geoghagen, A. 1989. A population study in Jamaica on the gall-midge Asphondylia boerhaaviae: a contribution to spatial dynamics. Journal of Animal Ecology 58:367-382.

GagnÉ, R. J. 1994. The Gall Midges of the Neotropical Region. Ithaca, Cornell University Press. 352p.

Hails, R. S. \& Crawley, M. J. 1992. Spatial density dependence in populations of a cynipid gall-former Andricus quercuscalicis. Journal of Animal Ecology 61:567-583.

Hammer, Ø.; Harper, D. A. T. \& Ryan, P. D. 2001. PASt: Paleontological Statistics Software Package for Education and Data Analysis. Palaeontologia Electronica 4:1-9.

Hawkins, B. A. \& GagNÉ, R. J. 1989. Determinants of assemblage size for the parasitoids of Cecidomyiidae (Diptera). Oecologia 81:7588.

Hijmans, R. J.; Cameron, S. E.; Parra, J. L.; Jones, P. G. \& Jarvis, A. 2005 . Very high resolution interpolated climate surfaces for global land areas. International Journal of Climatology 25:1965-1978.

Maeda, N.; Sato, S. \& Yukawa, J. 1982. Polymodal emergence pattern of the Machilus leaf gall midge, Daphnephila machilicola Yukawa (Diptera, Cecidomyiidae). Kontyû 50:44-50.

MAIA, V. C. 1999. Artrópodes associados às galhas de Cecidomyiidae (Diptera) em Eugenia rotundifolia (Myrtaceae) e Clusia lanceolata (Clusiaceae) em uma restinga do Rio de Janeiro, Brasil. Iheringia, Série Zoologia 87:75-79.

Maia, V. C. \& Tavares, M. T. 2000. Cordiamyia globosa Maia (Diptera, Cecidomyiidae), flutuação populacional e parasitóides (Hymenoptera) associados. Revista Brasileira de Zoologia 17:589-593
Maluf, J. R. T. 2000. A new climatic classification for the State of Rio Grande do Sul, Brazil. Revista Brasileira de Agrometeorologia 8:141-150.

Mani, M. S. 1964. Ecology of Plant Galls. The Hague, W. Junk Publisher. 434p.

McGeoch, M. A. \& Price, P. W. 2004. Spatial abundance structures in an assemblage of gall-forming sawflies. Journal of Animal Ecology 73:506-516.

MendonçA, M. S., JR. 2001. Galling insects diversity patterns: the resource synchronisation hypothesis. Oikos 95:171-176.

MendonçA, M. S., JR. \& Romanowski, H. P. 2002a. Natural enemies of the gall-maker Eugeniamyia dispar (Diptera, Cecidomyiidae): parasitoids and ants. Brazilian Journal of Biology 62:269-275.

Mendonç, M. S., JR. \& Romanowski, H. P. 2002b. Life-history of the gall-maker Eugeniamyia dispar (Diptera, Cecidomyiidae). Brazilian Journal of Biology 62:277-283.

Mendonça, M. S., JR.; Romanowski, H. P. \& Kraus, J. E. 1998. Broad overview of a gall-system: from plant anatomy to ecological interactions. In: CsóKa, G.; Mattson, W. J.; Stone, G. N. \& Price, P. W. eds. The Biology of Gall-Inducing Arthropods. St. Paul, MN. USDA General Technical Report, NC-199.

Numata, S.; Kachi, N.; Okuda, T. \& Manokaran, N. 2004. Delayed greening, leaf expansion, and damage to sympatric Shorea species in a lowland rain forest. Journal of Plant Research 117:19-25.

Parnell, J. R. \& Chapman, G. P. 1966. Observations on a gall midge (Diptera: Cecidomyiidae) infesting pimento (Pimenta dioica (L.) Merrill) in Jamaica. Marcellia 32:237-245.

Raman, A.; Schaefer, C. W. \& Withers, T. M. 2005. Galls and GallInducing Arthropods: An Overview of their Biology, Ecology, and Evolution. In: Raman, A.; Schaefer, C. W. \& Withers, T. M. eds Biology, Ecology, and Evolution of Gall-Inducing Arthropods Plymouth, Science Publishers. v.1, p.1-34

Redfern, M. \& Cameron, R. A. D. 1978. Population dynamics of the yew gall midge Taxomyia taxi (Inchbald) (Diptera: Cecidomyiidae). Ecological Entomology 3:251-263.

1993. Population dynamics of the yew gall midge Taxomyia taxi and its chalcid parasitoids: a 24-year study. Ecological Entomology 18:365-378.

Redfern, M. \& Hunter, M. D. 2005. Time tells: long-term patterns in the population dynamics of the yew gall midge, Taxomyia taxi (Cecidomyiidae), over 35 years. Ecological Entomology 30:8695

Santos, J. C. \& Fernandes, G. W. 2010. Mediation of herbivore attack and induced resistance by plant vigor and ontogeny. Acta Oecologica 36:617-625

Soné, K. 1987. Population dynamics of the pine needle gall midge, Thecodiplosis japonensis Uchida et Inouye (Diptera, Cecidomyiidae). Journal of Applied Entomology 103:386-402.

Williams, A. G. \& Whitham, T. G. 1986. Premature leaf abscission - an induced plant defense against gall aphids. Ecology 67:16191627.

WooL, D. 1990. Regular alternation of high and low population size of gall-forming aphids: analysis of ten years of data. Oikos 57:73-79

YuKaWA, J. 1987. Life history strategies of univoltine gall-making Cecidomyiidae (Diptera) in Japan. Phytophaga 1:121-139.

2000. Synchronization of gallers with host plant phenology. Researches on Population Ecology 42:105-113.

YuKaWA, J. \& RoHFritsch, O. 2005. Biology and Ecology of Gall-Inducing Cecidomyiidae (Diptera). In: Raman, A.; Schaefer, C. W. \& Withers, T. M. eds. Biology, Ecology, and Evolution of Gall-Inducing Arthropods. Plymouth, Science Publishers. v.1, p.273-304. 